\title{
ポリエチレンテレフタレート繊維の染色性を 支配する構造因子*
}

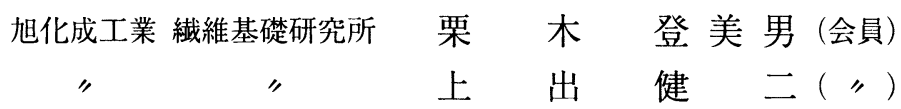

\section{Structural Factors Governing Dyeability of Poly (ethylene terephthalate) Fibers*}

\author{
by Tomio Kuriki and Kenji Kamide \\ Fundamental Research Laboratory of Fibers and Fiber-Forming \\ Polymers, Asahi Chemical Industry Co. Ltd., \\ 11-7 Hacchonawate, Takatsuki, Osaka
}

\begin{abstract}
An attempt was made for poly (ethylene terephthalate) (PET) fibers to correlate the amorphous supermolecular structure with the dyeability by disperse dye. For this purpose, the amorphous molecular packing density $(n)$ distribution $F^{\prime}(n)$, which can be evaluated from dynamic mechanical loss tangent tan $\delta$ vs. temperature curve in $\alpha_{a}$ dispersion region using the Manabe and Kamide theory, was chosen as an adequate parameter, representing the supermolecular stucture. Five PET fibers (75d/36f) having a wide variety of $F^{\prime}(n)$ were prepared by choosing adequate spinning velocity and annealing conditions. The fibers were dyed with Resolin Blue FBL at dyeing temperature $T_{d}$ ranging 90 to $130^{\circ} \mathrm{C}$ for time $t_{d}$ from 30 to $360 \mathrm{~min}$. The dye uptake $W$ for dyed PET fibers was determined. The upper limit of $n, n_{u}^{\circ}$, of the dye molecule penetration into the fiber solid was determined so as to hold the relation: $W=\int_{-\infty}^{n_{u}^{\circ}} F^{\prime}(n) \operatorname{dn}(k:$ the proportional coefficient). The $n_{u}^{\circ}$ increased with an increase in $T_{d}$ or $t_{d}$ and $k$ was found to be almost constant, regardless of the PET samples used, and the dyeing conditions. This strongly suggests that the dyeability of PET fibers is unabigously determined

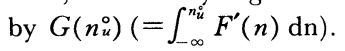

(Received Nov. 27, 1985)

* Part 8 of "Study on Regulation of Supermolecular Structure and Improvement of Dyeability under Atmospheric Pressure of

Poly (ethylene terephthalate) Fibers Spun at High Wind-Up Speed"

摘 要

PET 繊維の無定形領域における超高分子構造のパラメーターとして, 分子鎖の充填密度分布関数 $F^{\prime}(n)$ を利用し, 分散染料による染色性との関連を，より定量的に評価することを目的とする. 紡速及び熱処理条件を適切に選ぶことによ って, $F^{\prime}(n)$ を広い範囲に変化させた 5 種の PET 繊維に対する分散染料 Resolin Blue FEL の染色温度 $T_{d}: 90 \sim 130^{\circ} \mathrm{C}$, 染色時間 $t_{d}: 30 \sim 360 \mathrm{~min}$ における染着量 $W$ を測定した，Wと，染料の拡散し得る最高の分子鎖充填密度 $n_{u}^{\circ}$ 以下の弾性

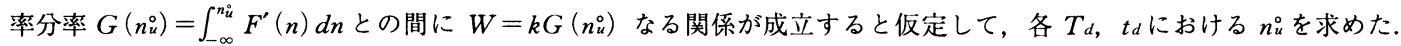
その結果, $T_{d}, t_{d}$ が増大するほど $n_{u}^{\circ}$ は大きくなり, 染色の拡散し得る領域は充填密度の高い部分へと拡大する. 又, 各 $T_{d}$, $t_{d}$ において求めた $G\left(n_{u}^{\circ}\right)$ とそれに対応する各試料の $W$ を結ぶ直線の勾配はほぼ一定值 $(265 \sim 280)$ である. 従って， $G$

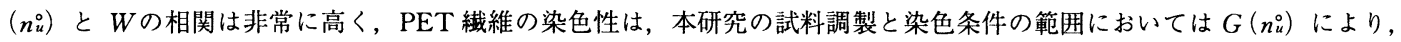
ほぼ義的に決定できる。

(昭和60年11月 27 日受理)
\end{abstract}

*本研究を「高速紡系ポリエチレンテレフタレート䄉維の超分子構造の制御と常圧可染化の研究」第 8 報とする. 


\section{1. 緒言}

ポリエチレンテレフタレート (PET) 繊維は, よく知られているように, キャリヤ（PET 繊維の 内部構造を弛緩し, 染料の拡散を助長する化合物で,

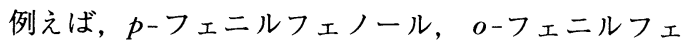
ノール等のフェノール類, モノクロロベンゼン, シ クロロベンゼン等のハロゲン化芳香族炭化水素類, ジメチルナフタレン, サリチル酸メチル, サリチル 酸エチル等のアルキル化芳香族化合物などである） を利用しないと, 分散染料による実用的な染着濃度 を得るためには， $120^{\circ} \mathrm{C}$ 以上の高温高圧下での染色 を必要とする。

PET 繊維を含めて, 染着速度, 飽和染着量など の染色性を支配する繊維の構造因子については，未 だ系統的な研究例はない.

最近, 結晶化度 ${ }^{1.2)}$ 及び複屈折 ${ }^{2)}$ よ゙のパラメー夕 が染色性と関連性が高いことが指摘された。これら の研究では, 結晶化度が増加するに伴い複屈折は増 大し，それらの值が大きくなるほど，染色性が低下 すると報告されている。しかし，熱処理したPET 繊維及び高速で紡系した PET 繊維では, 結晶化度, 複屈折が増大するにもかかわらず，分散染料の染着 量が増加する. 現象が見出されている ${ }^{3 \sim 6)}$.この事 実は, PET 繊維の染色性が, 単に（1-結晶領域量） で表わされる無定形領域量のみで決定されるのでは なく，無定形領域における分子鎖の凝集状態に分布 があり，その分布状態によりPET 繊維の染色性が 支配されることを示唆している。

喜多村られは，熱処理したPET 繊維について， 緎維の小角 $\mathrm{X}$ 線散乱強度が大きいほど, 又, 無定形 領域内のエチレングリコール残基のゴーシュ成分が 多いほど, 繊維内部への分散染料分子の浸透係数が 増大することを見出した。

Yonetake ら ${ }^{8)}$ は, ポリプロピレンフィルムが, あ る温度以上での熱処理により，染料の染着量が増加 し，それとともにX線回折法によって評価した結晶 化度及び結晶サイズ, 特に分子鎖方向の結晶サイズ が増加することを見出した。これらの事実から，モ ザイクブロックモデルを適用して, ラメラ晶表面の 上下に存在する無定形領域に，ラメラ晶側面に存在 する無定形領域よりも多くの染料が染着すると結論 した.

しかし, 上記の研究は, 無定形領域の超分子構造 を直接評価したものではない.

一方, 中山, 上出, 真鍋帛は, ポリアクリロニト リルフィルムへの分散染料の染着量が, 無定形領域
における分子鎖の充填密度分布と強い相関があるこ とを明らかにした。

第 6 報 ${ }^{10)}$ において, PET 繊維の結晶化度, 結晶 配向度が染色性と全く関連性がなく，動的粘弾性一 温度特性より決定される力学的損失正接 $\tan \delta$ のピ 一ク值 $(\tan \delta)_{\max }$ とピーク温度 $T_{\max }$ が染色性と相 関が高いことを明らかにした.すなわち，（tan $\delta)_{\max }$ が大なるほど無定形領域量が多く， $T_{\max }$ が低 いほど無定形領域における分子鎖の凝集状態が踈で ある，従って， $(\tan \delta)_{\max }$ が大きく，しかも $T_{\max }$ が低い纎維ほど染色性は良い. 特に, $(\tan \delta)_{\max }$ が 0.130 以上で, $T_{\max }$ が $105^{\circ} \mathrm{C}$ 以下の PET 繊維は常圧 可染性であると結論した。しかし，上記の染色性と， $(\tan \delta)_{\max }, T_{\max }$ との相関も実験的事実ではある が，厳密には定量性に欠ける.

本論文においては, 無定形領域の超分子構造を表 わすパラメータとして, 分子鎖の充填密度分布関数 $F^{\prime}(n)$ を用いることにより, 染色性と超分子構造 のより定量的な相関を明確にすることを試みた。

\section{2. 実 験}

\section{1 試料調製}

\section{A. ポリマー}

第 1 報 ${ }^{11)}$ と同じく，テレフタル酸とエチレングリ コールを連続法で重縮合した。このポリマーのオリ ゴマー含有量は $1.3 \%$ ，末端カルボキシル基は 30 $\mathrm{meq} / \mathrm{kg}$, Kamide ら ${ }^{12)}$ の方法で求めた粘度平均分子 量 $\mathrm{Mv}$ は $4.4 \times 10^{4}$ である.

\section{B. PET 减維}

2.1.Aのポリマーを用いて，第 1 報と同様の方法 で，巻取速度が $4 ， 5 ， 7$ 及び $8 \mathrm{~km} / \mathrm{min}$ で同一繊 度（75 d/36 f）の as-spun 繊維を作成した。また， 同時に紡速 $1.5 \mathrm{~km} / \mathrm{min} の$ 巻取速度で採取した 293 $\mathrm{d} / 36 \mathrm{f} の$ as-spun 繊維を, 延伸比 3.9 , 延伸温度 $130^{\circ} \mathrm{C}$ （ピン加熱方式）の条件で延伸し， $75 \mathrm{~d} / 36 \mathrm{f}$ の延 伸繊維を作製した。

\section{C. 熱処理}

2.1. B で紡系したPET 緎維を，第 3 報13) と同じ 装置を利用して, 表 1 に示す熱処理温度 $T_{\mathrm{a}}$, 熱処 理時間 $t_{a}$ で定長熱処理した。

表 1 に示す No. 1 〜 の試料は, 無定形領域中の 分子鎖充填密度分布 ${ }^{14-199}$ が幅広く異なる。

\section{2 測 定}

\section{A . 動的粘弾性}

第 1 報 $^{11)}$ と同様に，東洋ボールドウイン社製 
表 1 染色性, 構造測定試料

\begin{tabular}{c|c|c|c}
\hline \hline $\begin{array}{c}\text { 試料 } \\
\text { No. }\end{array}$ & $\begin{array}{c}\text { 紡 速 } \\
(\mathrm{m} / \mathrm{min})\end{array}$ & $\begin{array}{c}\text { 熱処理 } \\
\left({ }^{\circ} \mathrm{C} / \mathrm{sec}\right)\end{array}$ & 廷伸比 \\
\hline 1 & 4,000 & $250 / 1$ & - \\
2 & 8,000 & $250 / 1$ & - \\
3 & 7,000 & $170 / 1$ & - \\
4 & 5,000 & $170 / 1$ & - \\
5 & 1,500 & - & 3.9 \\
\hline
\end{tabular}

Rheovibron DDV- II c 型を用い, 測定周波数 110 $\mathrm{Hz}$, 昇温速度 $10^{\circ} \mathrm{C} / \mathrm{min}$, 乾燥空気中で力学的損失 正接 $(\tan \delta)$ の温度 $(T)$ 依存性を測定した. 得 られた $\tan \delta-T$ 曲線を真鍋, 上出ら ${ }^{14 \sim 19}$ の方法で解 析し, 無定形領域における分子鎖の充填密度分布関 数 $F^{\prime}(n)$ を求めた. 真鍋, 上出ら ${ }^{14 \sim 19)}$ は, 実在の 結晶性高分子の無定形領域は，充填密度を異にする 分子鎖群の集団であることを示した，その場合，実 測の $\tan \delta$ 及び Rouse-Tobolsky-Aklonis（R-T-A） 理論から計算される $\tan \delta R(n)$ と, 無定形領域に ついて規格化された充填密度分布関数 $F(n)$ との 間に(1)式の関係が成立する。

$$
\tan \delta=\int_{-\infty}^{\infty} F(n) \tan \delta_{R}(n) \mathrm{dn} \cdot
$$

ここで, $n$ は分子鎖の充填密度を表わすパラメー 夕で(2)式

$$
\dot{n}=\left(T_{\max }^{\prime}-T_{\max }\right) /\left(\Delta T^{\prime}{ }_{1 / 2}\right)_{R}
$$

( $T^{\prime}{ }_{\text {max }}$ はある要素に対応する $\tan \delta$ のピーク温 度, $\Delta T^{\prime}{ }_{1 / 2}$ は $\mathrm{R}-\mathrm{T}-\mathrm{A}$ 理論に基づいて計算された半 価幅）で定義される. $n$ が小さいほど分子鎖は疎に 充填されている。(1)式を利用すると， $F(n)$ を決定 できる. $F(n)$ を結晶領域を含めた試料全域に対し て規格化し，これを $F^{\prime}(n)$ とすると次の関係が成 立する。

$$
F^{\prime}(n)=f_{e} F(n)
$$

ここで $f_{e}$ は真鍋-上出理論より求めた無定形領域の 弾性率分率である。

\section{B. 染料染着量}

$0.5 \mathrm{~g}$ の各䋐維試料を, 長さ約 $1 \mathrm{~cm}$ に細断し, 第 2 報 ${ }^{16)}$ で使用した分散染料 Resolin Blue FBL 1.2 $\mathrm{g} / l$, 浴比200倍, $\mathrm{pH} 6$ の染浴中において, 染色温 度 $T_{d}: 90,100,110$ 及び $130^{\circ} \mathrm{C}$, 染色時間 $t_{d}: 30$, 60，120，180，240及び $360 \mathrm{~min}$ の条件下で染色した。 染色した試料を取出し, $20^{\circ} \mathrm{C}$ の蒸留水 $100 \mathrm{~m} l$ 中で $1 \mathrm{~min}$, よく攪拌して水洗を 2 回繰返した. 次いで 風乾後, 真空乾燥機中で, $40^{\circ} \mathrm{C}, 755 \mathrm{mmHg}$ の条 件で $48 \mathrm{~h}$ 乾燥した。乾燥試料の $0.1 \mathrm{~g}$ をり,

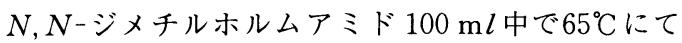
$3 \mathrm{~h}$, 試料に染着した染料の抽出を行い, 同に゙操作 を 3 回繰返した。これらの抽出液は混合し，全量を $N, N$-ジメチルホルムアミドにて $500 \mathrm{~m} l$ に稀橎し た。この染料溶液を島津製作所製ダブルビーム分光 光度計 UV-360 型にて比色し, 染料染着量 $W$ を決 定した。

\section{3. 実験結果及び考察}

図 1 に各試料の $\tan \delta-T$ 曲線を示す. 図 1 に示す $\tan \delta-T$ 曲線を, 真鍋, 上出ら ${ }^{14-19)}$ の方法により解 析して求めた $F^{\prime}(n)$ を図 2 に示す。なおここで充

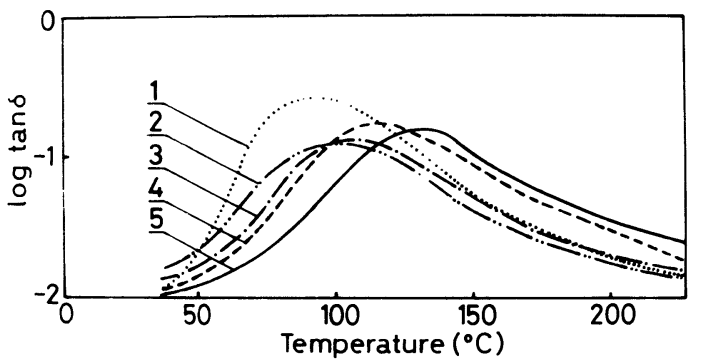

図 1 各試料の $\tan \delta-T$ 曲線

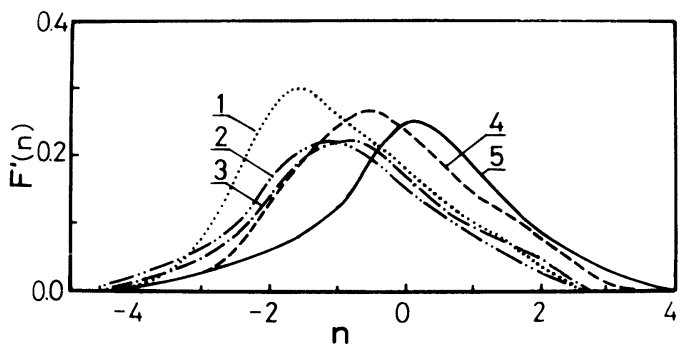

図 2 各試料の分子鎖充填密度分布関数 $F^{\prime}(n)$

填密度 $n$ が 0 となる要素として試料 5 の $T_{\max }=$ $128^{\circ} \mathrm{C}$ とった。

図 2 にみるように試料 1 ～ 5 の $F^{\prime}(n)$ は幅広く 変化している。図 1 及び図 2 ょり, 紡速 $4 \mathrm{~km} / \mathrm{min}$ で紡系した as-spun 繊維を, $25^{\circ} \mathrm{C}, 1 \mathrm{sec} の$ 条件で の熱処理した試料 1 は, 他の試料と比べて, ( $\tan$ $\delta)_{\max }$ が大きく $T_{\max }$ は低い。すなわち, 充填密度 $n$ の小なる領域を多く含むため染料染着量の多いこと が予想される．他の試料についても，熱処理温度 $T_{a}$ が, $250^{\circ} \mathrm{C}$ ものは $170^{\circ} \mathrm{C}$ ものより $n$ の小なる 領域, すなわち分子鎖充填密度の小さな無定形領域 量が多い.

無定形領域における分子鎖充填密度 $n$ の特定値 $n_{u}$ 以下の弾性率分率を $G\left(n_{u}\right)$ とすると,

$$
G\left(n_{u}\right)=\int_{-\infty}^{n_{u}} F^{\prime}(n) d n
$$

で定義される. 


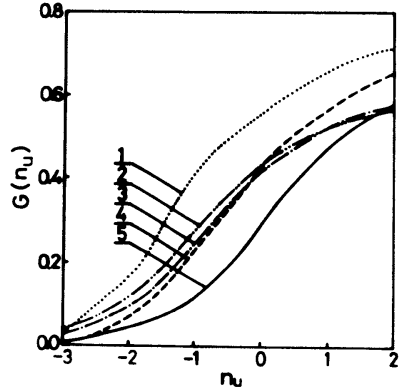

図 3 各試料についての特定の充填密度 $n_{u}$ 以下の 弾性率分率 $G\left(n_{u}\right)$

図 3 に, 各試料について $G\left(n_{u}\right)$ と $n_{u}$ の関係を 示す. $n_{u}<-0.3$ の領域では, 試料 $1 \sim 5$ の順に $G$ $\left(n_{u}\right)$ は大きい值を示すが, $n_{u}=-0.1$ で試料 3 と 4 の $G\left(n_{u}\right)$ は逆転し, $n_{u}=0.07$ で試料 2 と 4 の $G\left(n_{u}\right)$ が, $n_{u}=0.95$ で試料 2 と 3 の $G\left(n_{u}\right)$ がそ れぞれ逆転する。

図4(a)〜(d)にそれぞれ，T $T_{d}: 90 ， 100 ， 110$ 及び $130^{\circ} \mathrm{C}$ における染料染着量. $W$ の $t_{d}$ 依存性を示す. $T_{d}$ が高いほど， $t_{d}$ が長いほど $W$ は増加する．各 試料間で $W$ を比較すると， $T_{d} \leqq 110^{\circ} \mathrm{C}$ では，試料 $1 \sim 5$ の順に $W$ の值は大きい. しかし, $T_{d}=130^{\circ} \mathrm{C}$ においては, $t_{d} \geqq 120 \mathrm{~min}$ で試料 3 と 4 の $W$ は逆 転し, $t_{d} \geqq 150 \mathrm{~min}$ で試料 2 と 4 の $W$ は逆転する. この傾向は, 図 3 に示した各試料の $G\left(n_{u}\right)$ のそれ と一致する.

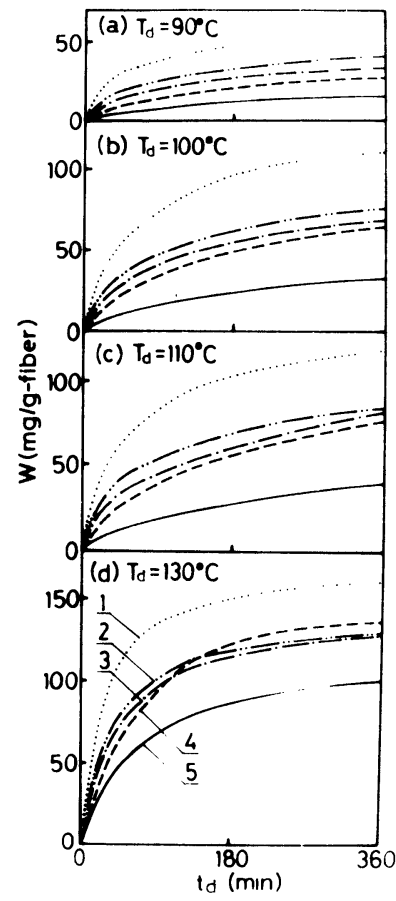

図 4 各試料の染料染着量 $W$ の染色時間 $t_{d}$ 依存性
いま，(1)無定形領域だけに染料分子が拡散し，(2) 染着量 $W$ と染色前の試料の $G\left(n_{u}\right)$ との間に $n_{u}=$ $n_{u}^{\circ}$ のときに限って比例関係

$$
W=k G\left(n_{u}^{\circ}\right)
$$

が成立すると考える（ $k$ は比例定数）.

(2)式では, 各試料の $G\left(n_{u}^{\circ}\right)$ が染色過程で変化し ないこと， $k$ が定数であることを仮定している.

第 3 報13)で示したように，染色過程中に扔いて， as-spun 繊維の $F^{\prime}(n)$ は変化し， $n$ の大なる領域 が多くなるが，熱処理物については，100ㄷおけ る染色過程中の $F^{\prime}(n)$ の変化は無視できる，従っ て，本論文において使用した試料については染色過 程中の $G\left(n_{u}\right)$ の変化はないといえる.

しかし, $k$ が定数であるという仮定は厳密には成 立しないであろう．例えば，分子鎖の凝集状態が疎 なほど染着量 $W$ が多く, 密な凝集状態の領域ほど $W$ は少ないと考えられる.すなわち, 分子鎖の凝 集状態の密な領域は染料の通過を許すくらいの大き さの空孔（自由体積）を生じにくい. 一方, 疎な領 域は, そのような空孔を数多く生成し得る。いいか えると, (2)式の $k$ は定数でなく $n$ の関数となる. 従って(2)式は

$$
W=\int_{-\infty}^{n_{\dot{\imath}}^{\circ}} k(n) F^{\prime}(n) d n
$$

と書ける。

(3)式では $k(n)$ が既知でなければ計算できない. そこで本論文では,

$$
\left.\begin{array}{ll}
k(n)=k, & n \leqq n_{u}^{\circ} \\
k(n)=0, & n>n_{u}^{\circ}
\end{array}\right\}
$$

とおいた。ここで， $n_{u}^{\circ}$ は染料分子が拡散できる 超分子構造の $n$ の上限である.

図 $5(\mathrm{a}) \sim(\mathrm{d}) に W$ と $G\left(n_{u}\right)$ の関係を，積分の上 限值 $n_{u}$ を変化させて示す.

$W$ と $G\left(n_{u}\right)$ の比例関係が成立するとき，すな わち，(2)式が成立するときの $n_{u}$ が求める真の $n_{u}^{\circ}$ ある。

本論文では，実験的には， $n_{u}^{\circ} は$ 図 5 のプロット した各直線の勾配の正接 $\tan \alpha$ と $W=0$ となると きの $G\left(n_{u}\right)$ の絶対值 $\left|\lim _{W \rightarrow 0} G\left(n_{u}\right)\right|$ との積 $\tan \alpha$. $\left|\lim _{W \rightarrow 0} G\left(n_{u}\right)\right|$ が最小となるときの $n_{u}$ の值を採用し た.

図 $6(\mathrm{a}) \sim(\mathrm{d})$ に図 $5(\mathrm{a}) \sim(\mathrm{d})$ に対応する $\tan \alpha \cdot \mid \lim _{W \rightarrow 0}$ $G\left(n_{u}\right) \mid$ と $n_{u}$ との関係を示す. 図 6 より, $\tan \alpha \cdot$ $\left|\lim _{w \rightarrow 0} G\left(n_{u}\right)\right|$ の最小点を与える $n_{u}$ を求め $n_{u}^{\circ}$ を決定 できる. 


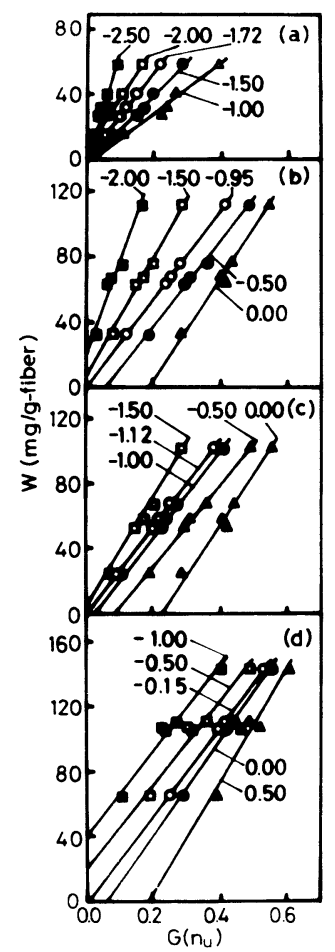

図 $5 W$ と $G\left(n_{u}\right)$ との関係

(a) $T_{d}: 90^{\circ} \mathrm{C}, t_{d}: 360 \mathrm{~min}$

(b) $T_{d}: 100^{\circ} \mathrm{C}, t_{d}: 360 \mathrm{~min}$

(c) $T_{d}: 100^{\circ} \mathrm{C}, t_{d}: 240 \mathrm{~min}$

(d) $T_{d}: 130^{\circ} \mathrm{C}, t_{d}: 120 \mathrm{~min}$

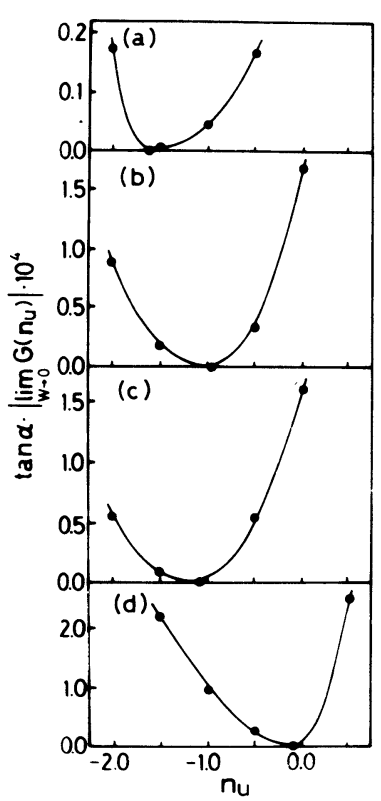

図 $6 \tan \alpha \cdot\left|\lim _{W \rightarrow 0} G\left(n_{u}\right)\right|$ との関係

図 6 より評価した $n_{u}^{\circ}$ の $t_{d}$ 依存性を図 7 に, $T_{d}$ 依存性を図 8 に示す．染料分子はまず無定形領域の ルーズな部分より拡散し， $t_{d}$ が経過するほど， $T_{d}$

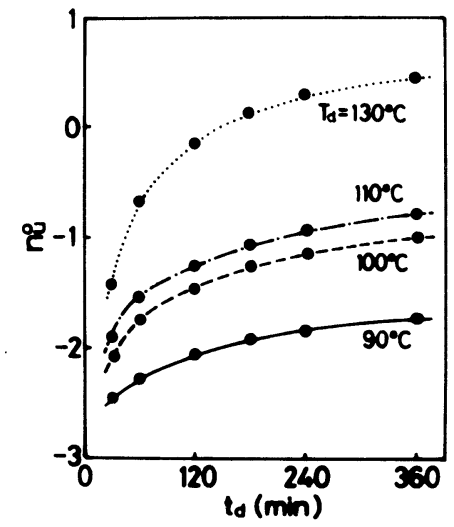

図 7 分散染料の拡散し得る最高の充填密度 $n_{u}^{\circ}$ の 染色時間 $t_{d}$ 依存性

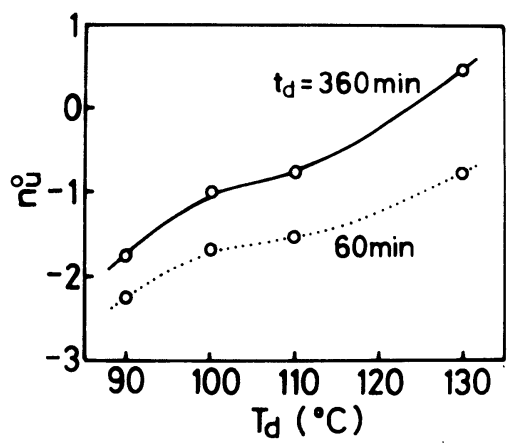

図 $8 n_{u}^{\circ}$ の染色温度 $T_{d}$ 依存性

が高くなるほど，分子鎖の充填密度の高い領域に拡 散する。

又，このようにして得た各 $T_{d}, t_{d} に$ における $n_{u}^{\circ}$ 用いて, $G\left(n_{u}^{\circ}\right)$ に対応する各試料の $W$ を結ぶ直 線を描くと,それらの勾配は, ほぼ一定值 (265 280) を示す（例えば，図 $5(\mathrm{a})$ (d)の白丸を結ぶ直線).

従って, $G\left(n_{u}^{\circ}\right)$ と $W$ の相関は非常に高く, PET 繊維の染色性は, 本研究の試料調製と染色条 件の範囲においては， $G\left(n_{u}^{\circ}\right)$ により，ほぼ一義的 に決定できる。

\section{謝辞}

本論文の染色実験の一部を担当して頂いた, 武庫 川女子大学家政学部学生二階堂宏子, 羽岡余志美の 両氏に感謝します。

\section{引用文献}

1) R. H. Peters ; Colour Age, Nov. 4, p. 3 (1982)

2) R. A. Moore and H.D. Weigmann; Text. Chem. Colour., 15, 197 (1983)

3）增子徹; 挠学誌，36，P 41 (1980)

4）清水二郎, 奥居徳昌, 鞠谷雄士; 䄉学誌, 37, T 135 (1981)

5）上出健二, 栗木登美男, 真鍋征一, 岩田道隆; 樴機誌, 38, T93 (1985)

6）栗木登美男, 上出健二, 真鍋征一, 岩田道隆；峨機誌，38, T 150 (1985) 
7) 喜多村一夫, 柴田二三男, 吉田善一 ; 蔵学誌, 27, 359 (1971)

8) K. Yonetake, T. Masuko, T. Shimanuki and M. Karasawa ; J. Appl. Polym. Sci., 28, 3049 (1983)

9）中山暢三, 上出健二, 真鍋征一 ; 䄉学誌, 33, T192 (1977)

10）栗木登美男, 上出健二, 小松義也；䄉機誌, 38, T 192 (1985)

11）上出健二, 栗木登美男, 真鍋征一, 岩田道隆; 㵶機誌, 38, T85 (1985)

12) K. Kamide, Y. Miyazaki and H. Kobayashi ; Polym. J., 9, 317 (1985)

13）栗木登美男, 上出健二, 真鍋征一, 岩田道隆；；緉機誌,
38, T 45 (1985)

14）真鍋征一, 上出健二, 中山暢三 ; ; 䄉機誌, 30, T 45 (1977)

15）真鍋征一, 上出健二, 中山暢三 ; ; 紻機誌, 30, T 55 (1977)

16）真鍋征一, 上出健二, 中山暢三 ; ; 繊機誌, 30, T 66 (1977)

17）真鍋征一, 上出健二, 中山暢三, 小林茂子 ; ; 緎機誌, 30 , T 85 (1977)

18）上出健二, 真鍋征一, 原正勝, 中山暢三；；䋐機誌， 31 , T1 (1978)

19) S. Manabe, and K. Kamide ; Polym. J., 16, 375 (1985) 